\title{
THE HOUSING MOVEMENT IN SEVILLE. FROM "DIGNIFIED HOUSING" TO 15M
}

\section{EL MOVIMIENTO POR LA VIVIENDA EN SEVILLA. DE LA "VIVIENDA DIGNA" AL 15M}

\author{
José Candón-Mena \\ Universidad de Sevilla \\ jcandon@us.es \\ http://orcid.org/0000-0003-1070-4987 https://orcid.ord/0000_0002-4159-3338 \\ Ibán Díaz-Parra \\ Universidad de Sevilla \\ ibandiaz@us.es
}

\author{
David \\ Montero-Sánchez \\ Universidad de Sevilla \\ davidmontero@us.es \\ https://orcid.org/0000-0003-2937-0438
}

\begin{abstract}
In recent times, Spain has seen the emergence of a number of social movements advocating for decent housing. This has been in parallel with the deepening and generalization of this problem for an important part of the population. These movements integrate political ideas and forms of collective action that have developed and matured over the last two decades in markedly different situations. This article proposes that, rather than disconnected groups and movements, we can speak of a long sequence of on-going mobilization with various waves of urban protests, which reached their maximum relevance under the economic crisis. This narrative takes the city of Seville as a case study and depicts the main features of this cycle as observed from an investigation based on direct participant observation.
\end{abstract}

Key-Words: Seville; 15M; squatting movement; decent housing movement; participant observation

\section{Resumen}

En los últimos tiempos, España ha sido testigo del surgimiento de una serie de movimientos sociales que abogan por una vivienda digna, paralelamente a la profundización y generalización de esta problemática para una parte importante de la población. Estos movimientos integran ideas políticas y formas de acción colectiva que se han desarrollado y madurado durante las dos últimas décadas en situaciones marcadamente diferentes. Este artículo propone que, más que grupos y movimientos desconectados, podemos hablar de una larga secuencia de movilizaciones en curso con varias oleadas de protestas urbanas, que alcanzaron su máxima relevancia bajo la crisis económica. El texto toma la ciudad de Sevilla como caso de estudio y describe las principales características de este ciclo como resultado de una investigación basada en la observación participante.

Palabras clave: Sevilla; 15M; movimiento okupa; movimiento vivienda digna; observación participante 


\section{Introduction}

In the following pages we hypothesize that it is actually possible to speak about a long, clearly connected, sequence of mobilization around the subject of decent housing since the mid 1970s in Spain, one undergoing different waves of protest. Rather than about isolated instances of protest, we argue that such mobilization cycle underwent a number of latent and manifest phases of mobilization and peaked in the context of the economic and political crisis that sparked the $15 \mathrm{~m}$ movement. Our analysis will specifically focus on the city of Seville in southern Spain. Here, wider national movements have very often translated into local struggles where the issue of housing has featured prominently. From this local perspective, our empirical work shows that each subsequent mobilization phase over this long period of time left behind a legacy of structures, discourses, identities and resources for collective action that resurfaced later on, giving a clear continuity to the social struggle around housing. The text also emphasizes the role played by veteran activists throughout the aforementioned cycle of mobilization.

Although our research specifically draws a line connecting phenomena such as the neighbor movement during the democratic transition or the okupa (squatter) movement in the 1980s (Carbonell, 1999; Martínez López, 2002, 2019 y 2020) through to more recent social struggles around issues such as gentrification and touristification (Díaz-Parra, 2008 and 2013; Fernández, Hernández and Barragán, 2019), our research mostly engages with the historical period extending between the emergence of the movement for Vivienda Digna [Dignified Housing] in 2006 (Haro and Sampedro, 2011; Aguilar and Fernández, 2010; García, 2011) and the impact of the 15m movement (Candón-Mena, 2013; Díaz-Parra and Candón-Mena, 2015), as well as subsequent actions by the Plataforma de Afectados por la Hipoteca [PAH, Mortgages Affected Platform] (Colau and Alemany, 2012), and the occupation of the so-called 'Corralas'1 in Seville from 2012 onwards. During these years a major shift is evident in the concrete nature of the housing problem in Spain as it went from being a well-defined problem, affecting a distinct minority of groups within Spanish society, to being a generalized and global issue (Díaz-Parra, 2013). This made possible for social movements to complete a transition from organizations focused on specific groups and problems around housing into platforms that attempt to confront the problem from a wider perspective ${ }^{2}$.

\section{Methodology}

Methodologically, our challenge, as scholars directly engaged in the housing movement in Seville has been to transform our political engagement in a strategic opportunity to undertake extensive research from within the movement. Therefore, our empirical work should be understood in the context of activist research (Fuster, 2009; Greenwood, 2007; Hale, 2006; Malo, 2004). Both José Candón-Mena and Iban

1 A 'corrala' is a common house in Andalusia designed with several corridors and balconies overlooking a central, indoors patio. They were typical and very popular in cities like Seville. Collective occupations taking place in Seville in the latter stages of the $15 \mathrm{~m}$ movement take their name after traditional 'corralas'.

2 Since the start of the crisis (late 2007) 4 million jobs have been destroyed. There are close to 6 million people unemployed and the unemployment rate is igher than $25 \%$, whichmeans that one in every four people of working age finds themselves unemployed. In the under 25 population it surpasses $50 \%$, meaning that half of all young people are unemployed. See http://www.ine.es/ prensa/epa_prensa.htm 
Díaz-Parra have featured prominently in the analyzed movements and have used their experience as the bases for this research. Methodological techniques used are based on processes of participant observation developed in Seville over the last 15 years in contexts such as the neighbor and okupa movement (AAVV EI Triangulo, CV Pumarejo, Coordinadora de Barrios en Lucha, CSOA Casas Viejas, CSOA Sin Nombre, CSOA La Fabrica de Sombreros, CSOA La Huelga), the Vivienda Digna movement in Seville, 15M (Asambleas del Barrio San Pablo-Santa Justa, Intercomisión de Vivienda 15m, PIVE) and also in the Corralas (La Utopía y La Alegría). Such observation techniques have allowed us to put together over a dozen of autobiographical narratives (Clandinin and Connelly, 1994; Blanco, 2010; De Miguel, 1996) and life stories (Bertaux, 2005; Pujadas, 1992) from participants and veteran activists in the vast majority of the analyzed social movements. Furthermore, the present article has also benefited from some of the previous academic work developed by the authors in the context of the okupa, Vivienda Digna and $15 \mathrm{~m}$ movements, including more than 30 semi-structured interviews (Vallés, 1997) and ten focus groups (Ibáñez, 1979; Callejo, 2001) involving activists in Seville. Finally, published work by one of the authors, Iban Díaz-Parra, over the housing-market and gentrification issues in Seville has been used in order to provide background information to our analysis of mobilization patterns around decent housing in the city (Díaz-Parra, 2010 and 2013). Our ultimate goal has been to define an ethnographical account of the housing movement that focuses mainly on its stakeholders, whether activists, scholars, policy makers, neighbors and/or the people affected by political and economic problems around housing.

\section{Theoretical framework}

The theoretical framework of this investigation is based on the major currents of the study of social movements; the Mobilisation of Resources Theory (RMT), and the New Social Movements (NSM). The synergy between both tendencies and the attempts to unify them in the eighties will be the point of departure for this analysis. With regard to establishing a connection between different housing movements some specific concepts from the theory of mobilisation of resources and the new social movements will be relevant.

With regard to the first, we will use the concept of 'cycles of protest' proposed by Tarrow, who defines it as 'a phase of intensification of the conflicts in the social system' (1994:263). The cycles of protest are characterized by an increase and diffusion of conflict due to the demonstrative effect of the first mobilisations, changes in the repertoire of confrontation as new cultural frames are tested, the appearance of new organisations and the radicalization of existing ones, and a growth in information and interactions between the mobilised groups and the authorities. The phase of decline or demobilisation is characterised by exhaustion and polarisation, the division between violence and institutionalisation, and strategies of recuperation and repression.

Although Tarrow includes the counter-movements that rise as a response to the first mobilisations, for our analysis we are particularly interested in the description of the phases that a concrete movement has to pass through, which after Its birth and expansion ends in decline. We intend to show how the housing crisis has produced various cycles of protest which after an intense period of mobilisation have ended, at first sight, disappearing. However, we begin with the hypothesis that the decline and disappearance of said movements in the public sphere does not signify their disappearance, but that we can consider them as successive periods in a long cycle of mobilisation which is maintained over time. 
Koopmans (2004) takes Tarrow's work as a point of departure in order to argue that instances of collective action are not independent and focuses on their connectedness, both in time and space, with other instances of collective action. Unlike Tarrow, however, Koopmans explains that the concept of a cycle implies the idea of a recurring sequence of events, speaking instead of 'waves of contention' with a strong increase and decrease phases in a moment of visible protest. Koopman defends the relevance of considering dynamic interaction among a multitude of contenders in order to understand how periods of 'normal politics' (Koopmans, 2004:41) can alternate with a surge of intense mobilization. His view depicts political change as a process marked by the attempts of various contenders to improve their position within specific power systems, adapting their repertoires of action and innovating in response to changes in the socio-political context.

From the perspective of new social movements, Melucci (1999) complements the ideas of Tarrow with a critique which he calls the 'myopia of the visible' which, according to the critique, characterizes the previous perspectives of studies of movements. According to Melucci the previous theories started from the existence of a movement to analyse afterwards when and how they mobilised, but the actual existence to start with of a collective subject is precisely what needs to be explained. The existence of a movement cannot therefore be treated as a fact but as the product of a process. The 'collective identity' would be the process by which the subjects produce collective structures of knowledge which are the result of emotional recognition and which move them to action and an intermediate level in which the individuals evaluate and recognise what they have in common and decide to act collectively. This distinguishes two levels in existence in the social movements, the 'level of latency' and the 'level of visibility'.

The 'level of latency' is for Melucci the greatest strength of the new movements. The importance of this phase is highlighted when the potential for a protest is examined, in contrast to the phase of visibility and the public demonstrations of collective action, which has been the focus of attention of previous theories. Critiquing in this way the 'myopia of the visible' is to say, the emphasis given to the mobilisation in itself over the deeper causes of it which exists in the system of reference previously created. It is in the level of latency, in the 'submerged networks', where alternative cultural codes are created and the alternative forms of social organisation which will represent the demands of the movement before the wider society in the level of visibility. The submerged networks are the 'laboratories' where cultural models and collective identities are experimented with. Thus, it is possible to take into consideration the idea that the different cycles of mobilisation around housing, defined a priori as independent movements, form part of the same cycle of protest in which every one of the stages of visible collective action are nothing more than episodes of activity connected by stages of latency in which the movement continues to be active, although without producing mobilisations in the public sphere.

One of the points of contact between RMT and NSM is exemplified in the concepts of 'formation of consensus' and 'mobilisation of consensus' proposed by Klandermans (1988) and the present similarities with the stages of latency and activity defined by Melucci and also with the periods of normal politics and waves of contention contributed by Koopmans. The first defines the previous phase before the mobilisation in which interpretations held in common are created, frames of reference and construction of new shared meanings which define the collective identity of the subjects of the movement. In this way they recover the cultural and subjective factors, the belief systems and the ideological component which the excessive rationalism and strategic focus of the RMT had discarded. The mobilisation of consensus would include many of the contributions 
of the RMT such as the important role of the organisations of the movement, the mobilisations of resources or the taking advantage of political opportunities.

In general, we can sum up the contributions of Tarrow, Koopmans Melucci and Klandermans as attempts to define the stages of mobilisation which go further than the stage of protests visible in the public sphere. Tarrow pays more attention to the stage of visible and active mobilization, but with the merit of pointing to the natural cycle of protests. For their part, Melucci, Koopman and Klandermans would point to the importance of previous stages prior to the mobilization or intermediate stages between different cycles of protests. Melucci talks about 'submerged networks' and about the 'level of latency' where cultural codes and identities of collective actors are created and negotiated through social interaction. Koopmans focuses on a more ecological approach, calling attention to the constant interaction of a number of actors across before, during and after a wave of contention. On the other hand, Klandermans points towards a previous 'formation of consensus' phase where social actors who would later on proceed to the 'mobilization of consensus' are constructed after gaining a consciousness of themselves as a group. Nonetheless, this 'mobilization of consensus' can happen previously while still in a latency phase where the movements try to circulate their proposals for collective action before going through with them and formulate them in the public domain. The following table summarizes the concepts used by the authors discussed in this text. They show what, generally, could be read as a latent and a manifest stage in the life of social movements.

Table I. Theoretical framework

\begin{tabular}{|c|c|c|c|c|}
\cline { 2 - 5 } \multicolumn{1}{c|}{} & Tarrow & Melucci & Klandermans & Koopmans \\
\hline Latent Stages & & Level of Latency & $\begin{array}{c}\text { Formation of } \\
\text { Consensus }\end{array}$ & Normal politics \\
\hline Visible Stages & Cycles of Protest & Level of Visibility & $\begin{array}{c}\text { Mobilisation of } \\
\text { Consensus }\end{array}$ & $\begin{array}{c}\text { Waves of } \\
\text { contention }\end{array}$ \\
\hline
\end{tabular}

The aforementioned concepts constitute the bases of our proposal's theoretical framework in accordance with our research's objectives and the proposed hypothesis. Further analysis would pay increased attention to such concepts in order to verify our hypothesis.

\section{Housing struggles in Seville: From Okupas to the Corralas}

First, we should mention previous struggles around housing problems at state-level which, although they cannot be considered as part of the wider cycle of mobilisation which we are examining here, still serve as historic reference points of previous mobilisations.

The first of these is the so-called tenants' movement which connected to the workers' movement in the early twentieth century in a number of ways. This tenant's movement was also deeply intertwined with urban, anarcho-syndicalist groups organising solidarity and struggle in the working class through popular ateneos (working class cultural centres). Several laws regulating tenancies, clearly favourable to tenants, from the period 1910-1920 were a direct response to this movement's demands and inaugurated a legal tradition which was to continue until the mid 1980s. 
The second of these struggles calls attention to the movement of neighbours' associations. Mostly during the 1960s and 19790s, this movement based its success on the connection between the management of basic necessities in common spaces, the neighbourhood, and a transformative, wider struggle that, from afar, can be seen just as an anti-Franco or pro-democracy, although it also displayed a strong radical and revolutionary component (Castells, 1983). Even when it was not the primary objective of neighbour's association, the struggle for access to housing was one of its fronts of action. In the last years of Francoism, as the accumulation of housing stock in Spain began (Capel, 1983), we see the first mass occupations of newly built homes. These occupations were closely related with the neighbours' movement and they primarily involved public housing stock, such as in the cases of Montjuic in Barcelona or La Ventanilla in Madrid (Dieste and Pueyo, 2003).

Closer in time and with a clearer connection to current struggles (mostly in terms of accumulated experience, transfer of activists and common memory of the struggles), we find the squatting or okupa movement. Up to 1994, the first wave of important occupations is underway in the big metropolis. Such occupations are normally regarded as a part of a wider, more general cycle of protest which included campaigns against large events, supranational organisations and neoliberal reforms. It was after the reform of the Spanish penal code and the inclusion of squatting as a crime, between the second half of the nineties and the first years of the twenty first century, which the squatting movement reached its highest levels of conflict and public visibility. In this context, squatting was framed as a youth phenomenon and occupied social centres (CSOAs, self-managed and squatted social centres) became the main objective of politically motivated squatting (Martínez López, 2003).

This cycle of protest was materialized in Seville around the campaign against the 1992 Universal Exposition which commemorated 500 years from the discovery and colonisation of America. The first public squat in Seville was part of this movement and took place in 1991 when the CSOA Cruz Verde was opened. The occupation continued until 1995. Previously there had been some experiences of occupying community spaces and public housing in the city, mostly connected to the local effervescence of the movement of neighbours' associations in the period of the political transition from the dictatorship to liberal democracy (Díaz-Parra, 2012). In 1995 five squats were evicted, including CSOA Cruz Verde and in 1996 El Lokal was opened. Although not a CSOA, El Lokal quickly became a reference point for the squatting phenomenon in those years. Between 2001 and 2007, a new generation of activists and squatters would occupy CSOA Casas Viejas. Although run by an anarchist oriented collective, CSOA Casas Viejas displayed all the recognisable okupa cultural codes and was clearly linked by its politics and its actions to the local tenants' movement and to the struggle against property speculation.

Three years later, in 2010, three new occupations continued to expand the connection between the okupa movement and neighbour's struggles initiated by previous CSOAs, prioritising social action around housing issues over the more identity and aesthetic focused tendencies of the movement. The CSOA Sin Nombre, squatted by libertarians ${ }^{3}$ close to Casas Viejas, quickly connected with the tenants struggles of San Bernardo. The support offered by CSOA Sin Nombre to collectives of neighbours threatened by gentrification would result in the collective occupation of a public housing building

3 Our use of the term 'libertarian' points explicitly towards anarchism in its combination of liberalist individual freedom and Marxist communalism (Chomsky, 2005). It is not our intention to link the term to neoliberal or anarcho-capitalist ideas defending the limitation of state action and complete market freedom, disregarding social solidarity, as often happens in Anglo-Saxon countries. 
in order to avoid evictions while denouncing the harassment of tenants (Díaz-Parra, 2008; Honorato, 2010). Such collaboration would later become an important reference point for more current occupations as it involved the occupation of homes rather than a social centre. Moreover, such occupation was led mostly by older women, a profile totally different from politically motivated squatting up till that moment.

In 2004, the occupation of La Huerta del Rey Moro, an abandoned wasteland which was turned into allotments for school groups, also displayed a strong involvement from neighbours and parents' associations from local schools. From the beginning, the approach towards La Huerta del Rey Moro as an occupied was more open to collaboration with the local administration compared to other occupied spaces mentioned before, even managing in this case to obtain funding from a participative budget experience put together by the Seville council. Last, the squatting of neighbours' centre El Pumarejo is notable for combining the defence of tenants harassed by the owner of the building, in a context of intense gentrification, and the squatting of a centre for meetings and activities as in other CSOAs. In the neighbours' centre El Pumarejo classic residents' associations, squatters and the local population came together. From the experience in EI Pumarejo and also out of a number of struggles in the historic centre of the city, the Liga de Inquilinos La Corriente [La Corriente League of Tenants] was born. Since then, La Corriente has been dedicated to the defence of poor tenants in Seville's city centre. From El Pumarejo, La Corriente also managed an 'Unidad Básica de Atención al Inquilino' (UBAI, Basic Unit of Assistance for Tenants), a legal counselling service on housing issues (Díaz-Parra, 2010).

In 2007 Casas Viejas was evicted. The eviction attracted a great deal of attention due to a resistance tactic where two squatters chained themselves in a tunnel, managing to delay the eviction by 36 hours (Agudo, 2010). Squats of CSOAs in the historic centre continued up to the present day although with a shorter average lifespan, firstly CSOA Fabrica de Sombreros (2008-2009) and later CSOA La Huelga (2010-2012.)

The vitality of the squatting movement in Seville is notable, making it one of the most visible along with Madrid and, above all, Barcelona in the Spanish context. In Seville the movement was characterized by a strong involvement in the classic local residents' struggles and by a greater openness which allowed collaboration between very different collectives. Although driven mostly by libertarian activists, the okupa movement also made space for citizen focused activists and groups, as well as for other actors with more reformist concerns. It was in the occupied CSOAs that many of the struggles of those years flowed together. Throughout the first decade of the twenty first century, the squatting phenomenon had an important weight in the struggles for housing, influencing the movement for Vivienda Digna [Decent Housing] and later $15 \mathrm{~m}$. The accumulated experience in the different politically motivated squats we have examined has meant that in Seville, as well as the halting of evictions which has occurred all over Spain after $15 \mathrm{~m}$, the occupation of dwellings for rehousing evicted people has been a characteristic and pioneering form of action which stands out in the Spanish context.

As well as the squatting movement and its global critique of the current forms of managing housing resources, in the period prior to the recent blossoming of the housing movement, there existed a different series of socio-political collectives which acted over the housing needs of particular groups. Over the last two decades, several movements arose with the intention of intervening around the concrete problem of gentrification and of the housing precariousness of certain strata of the working class, mostly in relation to older, impoverished tenants who were culturally rooted in the historic workingclass neighbourhoods in collectively rented buildings. In Seville, the aforementioned 
occupations of San Bernardo 52, the Plataforma de Inquilinos Amenezados [Platform of Threatened Tenants] and the Liga de Inquilinos La Corriente are particularly relevant cases. Also, the persistence of slums would be tackled by different associations, especially the Asociación Pro Derechos Humanos de Andalucía [APDHA, Pro-Human Rights Association of Andalusia]. Arquitectura y Compromiso Social [ACS, Architechture and Social Commitment], along with the vestiges of the old neighbourhood movement, would also play a relevant role in the battle against sub-standard housing. Problems related to obsolescence and to the need for rehabilitation of the functionalist housing estates built during the 1960s and 1970s were addressed by platforms such as the Federación de Entidades de Alcosa, Tres Barrios-Amate or Nosotros También Somos Sevilla during the first decade of the $20^{\text {th }}$ century.

The movement for Vivienda Digna entered the scene on a national level in 2006 focused on the problems of young people to leave their parents' home in an economic context of an extremely sharp rise in prices. The movement came out of a spontaneous and anonymous call out by email to hold a sit-in in the squares of the major cities of Spain on $14^{\text {th }}$ of May 2006. The success of the call out started a period of mobilisations, allowing the formation of a certain number of new activists, especially in the big cities where the housing problem was most acute. In contrast to previous housing movements, Vivienda Digna managed to make the housing question a central political issue, inheriting from the squatting movement a politics of a global critique of the management of housing resources. In time, the movement would connect directly with $15 \mathrm{~m}$, being one of its main forbearers and also the seed of organisations like $\mathrm{PAH}$, a notable protagonist of the current housing struggle (Candón-Mena, 2013:21-25).

The assemblies for Vivienda Digna, which sprung up after the first sit-in and were later called $V$ de Vivienda, would become the main structures of mobilisation of the movement. The movement had important repercussions and great levels of social acceptance, as well as it managed to have at least a symbolical influence in wider politics, turning the housing issue into an important point in the local elections of May 2007. In the same year, housing became the main problem of Spaniards according to a poll by the Centre of Sociological Investigations ${ }^{4}$. The demand that state comply with article 47 of the Spanish Constitution, which refers to the right of all citizens to housing; slogans like 'Qué pasa, qué pasa, que no tenemos casa' [What's up, what's up, we don't have a house] and of course the organisational structures created by the movement itself, such as the PAH, formed in Barcelona in 2009, undoubtedly represent the main legacy of the assemblies for Vivienda Digna. This movement also saw the consolidation of activist uses of digital technology in line with protests in 2004 following the $11 \mathrm{M}$ terrorist attacks in Madrid (Sampedro, 2005). The success of the massive, anonymous call-out by email that initiated the movement legitimated this new form of action which was to be used later by $15 m$ (Candón-Mena, 2009).

In Seville a local assembly for Vivienda Digna was set up and remained active between 2006 and 2007. It mainly replicated mobilisations at a national level, but also staged their own protests at draws celebrated by the council for social housing allocation. Housing activists and the squatting movement were to be very present in the Vivienda Digna assemblies in Seville, with weekly meetings in CSOA Sin Nombre. These assemblies integrated new activists along with veterans of the housing struggle, such as members of La Liga de Inquilinos La Corriente, ACS, APDHA or activists from different occupied social centres.

4 See http://www.cis.es/cis/export/sites/default/-Archivos/Indicadores/documentos_html/TresProblemas.html 
An important part of the activists who participated in the Vivienda Digna assemblies would become the driving force for the platform Barrios en Lucha [Neighbourhoods in Struggle] which was active between 2008 and 2011. Barrios en Lucha tried to bring together the diversity of problems and militant struggles around the housing problem, still in notably fragmented manner. Collectives which had come together during the worse of the housing bubble collaborated through Barrios en Lucha which also included more traditional neighbourhood associations from peripheral working class areas such as the Federación de Entidades de Alcosa (FEA) or the neighbours' association La Bachillera, both embroiled in conflicts with the administration. These and other previously mentioned struggles, come together under the umbrella of Barrios en Lucha despite a notable diversity of strategies and problems within the wider framework of housing and habitability.

In 2011, the $15 \mathrm{~m}$ movement represented a clear turning point in the social response against the crisis, giving a crucial impetus to local struggles across the whole country. Initially, the existing structures in Seville did not pay much attention to the first national demonstration on Sunday, May $15^{\text {th }}$, which started the movement. For instance, the Week of Social Struggle, organised by Barrios en Lucha for that same weekend, failed to officially call for members to attend the demonstration on Sunday. Many of them did, though, and very soon the local structures of Barrios en Lucha converged in the street assemblies of $15 \mathrm{~m}$. If, at first, $15 \mathrm{~m}$ made wide-ranging demands around issues such as the improvement of the democratic system and a general denounce of political elites and national economic policies, it did not take long for the movement to get in touch with the neighbourhoods and converge with the existing struggles. The critical moment in this process points towards the necessary decentralization of the general assemblies in encampments all around Spain once the decision to lift the protest camps had been made. The continuity of the movements was placed in each neighbourhood and villages so that they could reproduce the assemblies that took place in the protest camps. In the barrios, the overarching political demands connected with local and concrete issues. Here, the housing situation presented itself with the greatest urgency.

In Seville, this process was led mainly by activists from Barrios en Lucha. In the neighbourhood assemblies previous organisations and traditional activists met a new generation of protesters mobilised by $15 \mathrm{~m}$ (Díaz-Parra and Candón-Mena, 2014), Barrios en Lucha was succeeded by the so-called Housing Commission of the $15 \mathrm{~m}$ movement. The new Housing Commission integrated all previously mentioned social movements, the main organisations which had worked on the housing question in the last decade (Liga de Inquilinos, APDHA, ACS and some others) and other platforms of neighbours from the working-class periphery of the city. It became a co-ordinating space for most politically active people around housing in Seville.

Nationally, the $15 \mathrm{~m}$ movement allied itself with the PAH in order to stop evictions in a new wave of mobilisation that began in Madrid on the 15th of July. The practice that was repeated in other cities. In that same week, protest actions bringing together activists from $15 \mathrm{~m}$ and the $\mathrm{PAH}$ managed to halt a number of evictions in different Spanish cities (Díaz, 2011). On July 19th, as part of a new strategy within the $15 \mathrm{~m}$ movement activists began the occupation of abandoned, clearly linking $15 \mathrm{~m}$ to the okupa movement. In Zaragoza, a mass demonstration ended with the occupation of a building belonging to a bank with the intention to turn it into the headquarters of the post-encampment $15 \mathrm{~m}$ movement in the city. However, activists were evicted shortly afterwards. A longer-lasting experience took place in Cádiz where the indignados took over the Valcarcel baroque palace. These types of actions were to continue 
in the autumn of 2011 when the global demonstration of October 15th ended with nearly simultaneous occupations of buildings in Madrid (Hotel Madrid) and Barcelona (Edifici 150). Also, already existing squatted social centres acted from the beginning as meeting places and support centres for protesters. Occupation meant an addition to the repertoire of confrontation displayed by $15 \mathrm{~m}$, pointing towards influence of the squatting movement and foregrounding the strategy of intervening to halt evictions, on the one hand, and rehousing the displaced people on the other.

After the most visible phase of $15 \mathrm{~m}$ and its large mobilisations (May, $15^{\text {th }}$ and the ensuing camps; June 19th and October $15^{\text {th }}$ demonstrations; and the May $12^{\text {th }}-15^{\text {th }} 2012$ commemoration of the $15 \mathrm{~m}$ anniversary), the struggle turned progressively towards local issues, particularly towards halting evictions which ended up becoming a trademark of the movement after 2011. Due to the worsening of the crisis and the spectacular rise in unemployment, objective conditions favoured intensification in the struggles for housing which were also encouraged by empowerment and accumulated experience.

In Seville, the Housing Commission held its first public event with a call-out for a demonstration against evictions in October 2011. This demonstration ended with the occupation of Mercado Provisional de la Encarnación, situated right next to the plaza where the $15 \mathrm{~m}$ camp was settled few months back. This occupation would be evicted relatively quickly, without giving activists time to make real use of the space. On the other hand, the movement in Seville had been issuing calls to halt evictions since the month of July. After October, this activity began to be organised directly from the Housing Commission and/or from the different $15 \mathrm{~m}$ assemblies in the city neighbourhoods. An eviction halted on December $1^{\text {st }} 2011$ in Torreblanca, a peripheral working-class area, was particularly relevant, as it was attended by a great number of neighbours.

A phase of structure consolidation ensued, which included organizing a network of informative points called Puntos de Información sobre Vivienda y Encuentro [Housing advisory service and meeting point, PIVE] where a lawyer and several $15 \mathrm{~m}$ activists would offer legal counselling and information to concerned neighbours. It is important to point out that the first of these PIVEs is in fact the already mentioned housing advice service offered by the Liga de Inquilinos and located in the neighbours' centre of El Pumarejo, which had been running since 2003. It was actually this model which was replicated in the subsequent PIVEs.

In February 2012, the Housing Commission called a press conference where it presented a statement on the number and distribution of evictions in the city, announcing at the same time the founding of the tenth PIVE. Later on, they would reach a total number of thirteen that year, spread across the metropolitan area and different neighbourhoods in Seville. It is through the actions in these PIVEs that the first groups of people severely affected by housing problems, including mortgage holders threatened with eviction, tenants who cannot meet their rent payments and people who have already been evicted, began to form.

Very soon, also the Seville movement would begin the collective occupation of empty buildings (mainly new, unsold blocks of flats with bankrupt developers) in order to rehouse evicted families. In May of 2012, with the support of the local $15 \mathrm{~m}$ assembly, a total of 38 families' squatted four empty buildings owned by a bank, naming it Corrala Utopia $^{5}$. The example spread and on June $5^{\text {th }}$ five families decided to occupy Corrala

5 The occupation and later eviction at Corrala Utopía provoked significant tensions within the regional government in Andalusia, then a coalition between PSOE and IU. The eviction was used as an excuse by the regional president Susana Díaz (PSOE) in order to relieve Elena Cortés (IU) of her position as Housing Minister resulting later on in the fall of the coalition government. 
Conde Quintana; in August, another five families opened up Corrala La Alegria, the only one which was to be evicted only a month later. In the following months, three more Corralas were opened in the municipal boundary of Seville, and another four in the metropolitan area, housing a total of 145 families with the support of the PIVEs and the barrio assemblies of $15 \mathrm{~m}$.

To date, the Corralas remains the last significant episode in a long struggle for decent housing in the city of Seville. Corralas became spaces where the okupa movement, neighborhood associations, new $15 \mathrm{~m}$ activists and movements for decent housing converged and collaborated in a number of ways. After the evictions, public demonstrations and collective action regarding decent housing in the city remained low partly coinciding with the end of a long active sequence of mobilization and also in the wake of institutional action regarding housing by Podemos and other local initiatives such as Participa en Sevilla which would bring together many of the activists involved with the corralas. Nonetheless, high rent prices and the emergence of Airbnb have since then accelerated gentrification and touristification in Seville, promoting in turn the apparition of fledgling social initiatives such as the CACTUS collective (Fernández, Hernández and Barragán, 2019).

\section{Interconnected movements}

The review of the recent history of housing struggles in Seville is intended to act as a nexus allowing us to connect different movements in order to explore our main hypothesis, that is, the existence of a long cycle of mobilisation for housing going further than concrete, isolated episodes of mobilisation.

The interconnectedness between apparently independent movements takes various forms. First, there is a transfer of activists between movements. Throughout their political trajectory, the same activists reappear in many of the movements we have mentioned, accumulating experience and practical skills along the way. A significant number of organisations also maintain their commitment to tackling housing problems throughout different movements and political contexts. Arguments and slogans born in the context of a particular movement are re-used in later ones. Therefore, several groups share common cultural frames, a collective memory, as well as modular forms of action which are repeated.

As we have seen, in the struggles for housing in Seville, both squatting and tenant activists would swell later on the ranks of new movements, such as Vivienda Digna or $15 \mathrm{~m}$. Sevillian activists have participated in various occupations of social centres; the same ones took active part in the assemblies of the movement for Vivienda Digna; later on, they would be there in the occupation of squares by the $15 \mathrm{~m}$ movements; they participated and promoted the Corralas.

Meeting spaces also play a significant part in maintaining continuity among different movements. The CSOA Sin Nombre, opened up by the squatting movement, held local assemblies for Vivienda Digna. The Housing Commission and some neighbourhood assemblies of the $15 \mathrm{~m}$ movement are frequently held in the offices of associations from the old neighbours' movement. Spaces like the neighbours' centre of El Pumarejo or the offices of APDHA have held press conferences about future housing mobilisations, popular actions against evictions and other related events.

Practical skills used by activists in specific instances of mobilisations were previously used in other contexts. Technical skills learned by activists in the okupa movement, 
from forcing a lock to installing electricity and water, have been used later on in the occupation of San Bernardo 52 or in the new Corralas after $15 \mathrm{~m}$. Over the years, lawyers close to these movements have accumulated knowledge about the specific laws which penalize squatting. Such experience has been key, for instance, when it came to maintaining a network of legal advice and counselling centres during the $15 \mathrm{~m}$ movement. Social workers and architects working within the movements have also acquired useful knowledge over time in relation to aspects such as the best way to deal with people who have been evicted or the need to establish safety standards in occupied buildings. Activist use of information and communication technologies, used mostly from Vivienda Digna onwards, becomes key at $15 \mathrm{~m}$, for instance in order to issue anonymous calls to action through social networking sites.

Another important confluence points towards political discourses and the slogans used in each movement. We have already mention the slogan 'Qué pasa, qué pasa, que no tenemos casa' (What's up, what's up, we don't have a house), popularized by the movement for Vivienda Digna, but which also commonly heard in $15 \mathrm{~m}$ demonstrations. The cultural framework used by Vivienda Digna, anchored in a particular demand for the compliance with article 47 of the Spanish Constitution, is used subsequently by $15 \mathrm{~m}$ in order to halt evictions in the Corralas. The discursive frame of reference used by APDHA, and centred in the Universal Declaration of Human Rights, would be used later on as a different line of against the eviction in the Corralas. In the area of concrete demands, the squatting of empty homes, demanding their use in exchange for a social rent, was also put forward previously by activists during the occupation of San Bernardo 52, and again would be used later on as the main demand of the families in the Corralas.

The construction of identities has an accumulative effect, creating new aesthetic forms and different ways to understand collective action. It was the movement for Vivienda Digna which initiated the tendency to assume more open identities in an attempt to connect with a wider public. This would be later on a conscious task of the organizers of $15 \mathrm{~m}$ which appealed to normal people of different ideological orientations. Citizen-based and reformist tendencies would create reticence among collectives of a more radical nature. Slowly at first, faster after the $15 \mathrm{~m}$ decentralization process to the barrios, the movement would increasingly incorporate a more recognizably leftist discourse.

Posterior episodes of mobilisation would also create a number of structures later incorporated to new social movements. The PAH is paradigmatic in this respect. At first, it mostly incorporated activists from the declining movement for Vivienda Digna and, after years of silent struggle, these same activists would attract a greater deal of attention through $15 \mathrm{~m}$, as they received the support of assemblies. The whole process resulted in many more activists joining ranks of the $\mathrm{PAH}$ and also in the growth of many local organisations concerned by housing issues. Successive waves of mobilisation therefore tend create and consolidate specific organisations and useful structures of mobilisation which would, in turn, promote future social action and the integration of new activists.

Table II shows patterns of interaction between most mentioned collectives based on the participation of activists who identified themselves as members of several organizations. Although the Housing Commission ended up coordinating most of the housing movement in Seville, particularly since the emergence of the first corals, several organizations opted not to join, mostly working class neighbour associations that worked with Barrios en Lucha. Nonetheless, the table shows a strong connection between different collectives and a high number of shared members. 
Table II. Interaction between collectives through common membership

\begin{tabular}{|c|c|c|c|c|c|c|c|c|c|}
\cline { 2 - 10 } \multicolumn{1}{c|}{} & HC & VD & LI & Squat & ACS & APDH & BL & PAH & NP \\
\hline HC & $\mathrm{X}$ & $\mathrm{X}$ & $\mathrm{X}$ & $\mathrm{X}$ & $\mathrm{X}$ & $\mathrm{X}$ & $\mathrm{X}$ & $\mathrm{X}$ & \\
\hline VD & $\mathrm{X}$ & $\mathrm{X}$ & $\mathrm{X}$ & $\mathrm{X}$ & $\mathrm{X}$ & & $\mathrm{X}$ & $\mathrm{X}$ & \\
\hline LI & $\mathrm{X}$ & $\mathrm{X}$ & $\mathrm{X}$ & & & & $\mathrm{X}$ & $\mathrm{X}$ & \\
\hline Squat & $\mathrm{X}$ & $\mathrm{X}$ & & $\mathrm{X}$ & & & $\mathrm{X}$ & & \\
\hline ACS & $\mathrm{X}$ & $\mathrm{X}$ & & & $\mathrm{X}$ & & & & \\
\hline APDH & $\mathrm{X}$ & & & & & $\mathrm{X}$ & $\mathrm{X}$ & & $\mathrm{X}$ \\
\hline BL & $\mathrm{X}$ & $\mathrm{X}$ & $\mathrm{X}$ & $\mathrm{X}$ & & $\mathrm{X}$ & $\mathrm{X}$ & & $\mathrm{X}$ \\
\hline PAH & $\mathrm{X}$ & $\mathrm{X}$ & $\mathrm{X}$ & & & & & $\mathrm{X}$ & \\
\hline NP & & & & & & $\mathrm{X}$ & $\mathrm{X}$ & & $\mathrm{X}$ \\
\hline
\end{tabular}

HC: Housing Commission; VD: Vivienda Digna; LI: Liga de Inquilinos; Squat: Squatting Movement; ACS: Arquitectura y Compromiso Social; APDH: Asociación Pro Derechos Humanos de Andalucía; BL: Barrios en Lucha; PAH: Plataforma de Afectados por la Hipoteca; NP: Working class neighbourhoods' platforms

Table III collates the lifespan of the main squatted social centres and the periods of activity of some of the aforementioned organisations in the period between 1991 and 2012. It shows a clear continuity in the different struggles for housing, one articulated around different spaces and collectives which did manage to maintain interaction during intermediate periods (Liga de Inquilinos, ACS or different CSOAs, for instance) and benefited from the contribution of new activists and novel structures during periods of greater activity.

Table III. Timeline of collectives for housing and squatted social centres

\begin{tabular}{|c|c|c|c|c|c|c|c|c|c|c|c|c|c|c|c|c|c|c|c|c|c|}
\hline \multicolumn{22}{|c|}{ Date } \\
\hline 91 & 92 & 93 & 94 & 95 & 96 & 97 & 98 & 99 & 00 & 01 & 02 & 03 & 04 & 05 & 06 & 07 & 08 & 09 & 10 & 11 & 12 \\
\hline \multicolumn{5}{|c|}{ - CSOA Cruz Verde } & \multicolumn{5}{|c|}{ - El Lokal } & \multicolumn{7}{|c|}{ - CSOA Casas Viejas } & & & & & \\
\hline & & \multicolumn{20}{|c|}{-Arquitectura y Compromiso Social } \\
\hline & & & & & & & & & & & & \multicolumn{10}{|c|}{-Liga de Iniquilinos La Corriente } \\
\hline & & & & & & & & & & & & & \multicolumn{9}{|c|}{$\begin{array}{l}\text { - CSOA Sin Nombre } \\
\text { - Huerto del Rey Moro } \\
\text { - Centro Vecinal Pumarejo }\end{array}$} \\
\hline & & & & & & & & & & & & & & & & & \multicolumn{2}{|c|}{$\begin{array}{c}\text { - CSOA } \\
\text { Fabrica } \\
\text { de } \\
\text { Som- } \\
\text { breros }\end{array}$} & \multicolumn{2}{|c|}{$\begin{array}{l}- \text { CSOA } \\
\text { La } \\
\text { Huelga }\end{array}$} & \\
\hline & & & & & & & & & & & & & & & \multicolumn{2}{|c|}{$\begin{array}{l}- \text { Vi- } \\
\text { vienda } \\
\text { Digna }\end{array}$} & & & & & \\
\hline & & & & & & & & & & & & & & & & & \multicolumn{4}{|c|}{$\begin{array}{l}\text { - Barrios en } \\
\text { Lucha }\end{array}$} & \\
\hline & & & & & & & & & & & & & & & & & & & \multicolumn{3}{|c|}{$\begin{array}{l}\text { - } 15 \mathrm{~m} \text { Housing } \\
\text { Commissions }\end{array}$} \\
\hline & & & & & & & & & & & & & & & & & & & & & $\begin{array}{c}\text {-PIVE } \\
\text {-Corralas } \\
\text { - PAH } \\
\text { Sevilla }\end{array}$ \\
\hline
\end{tabular}




\section{Conclusions}

This research has demonstrated a continuity in struggles for housing, taking the city of Seville as a case-study. As we have seen, such continuity manifests itself in multiple forms, from the transfer of activists to the composition of the main co-ordinating structures in each movement, the use of shared slogans, demands and cultural frames (used and re-used in new phases of mobilisation) and the accumulation of knowledge and practical experience that is put to use in different movements over time.

Along with Tarrow, it is possible to identify different 'cycles of protest' in the examined case-study, such as the movement for Vivienda Digna or the more widely well-known $15 \mathrm{~m}$ movement. However, considering mostly Melluci and Klandermans' contributions, it is also possible to argue for the existence of a long cycle of mobilisation around housing issues where previous cycles of protest represent visible stages in a wider movement that remains latent during intermediate periods. Along with Mellucci, we can then apply the concept of 'submerged networks' to, for instance, the national activity of the PAH since its founding in 2009 up to its renewed line of action from 2011 onwards. In this light, Barrios en Lucha (2008-2011) represents a nexus between a declining Vivienda Digna movement in 2008 up to the emergence of the $15 \mathrm{~m}$ Housing Commission in 2011. Moreover, different CSOAs seem also to have played a pivotal role within this long cycle of mobilisation, as they represent a crucial reference point for activists at different moments in time and set a clear precedent for actions such as the occupation of the Corralas.

Although the intermediate collectives developed a continuous activity at local level during the examined period, it is undoubtedly in the period of greater social relevance, and in a propitious context defined by a rampant economic crisis and by the loss of legitimacy among political institutions, when initiatives around housing issue gained public recognition and managed to connect more successfully with the population, attracting new activists. Considering this, we can take Melucci's definition of latent and activity phases in order to analyse the activities of a number of collectives in different temporal periods as part of a general housing movement in the city of Seville. Intermediate activities undertaken by these collectives contributed to what Klandermans defines as 'formation of consensus', as a multitude of open seminars, debates and conversations between activists created then a fertile ground for posterior instances of mass mobilisations. In turn, periods of maximum activity reinforced consensus and provided activists and local collectives with enough energy to continue their activities after a decline in the mobilisation cycle.

We therefore consider our initial hypothesis to be correct. In Seville, a general housing movement has managed to maintain for years the confrontation with governing elites. Movements like Vivienda Digna or $15 \mathrm{~m}$ did indeed decline; however, this does not imply their complete disappearance, as their practices, political ideas and structures of mobilization were to resurface once new structures of political opportunity, objective conditions and the general context made it possible.

\section{Authors' contributions}

Concept and design, Jose Candón-Mena and Ibán Díaz-Parra; Methodology, Jose Candón-Mena and David Montero-Sánchez; Data collection, Jose Candón-Mena and Ibán Díaz-Parra; Analysis and interpretation, Jose Candón-Mena, Ibán Díaz-Parra and David Montero-Sánchez; Preparation of the original draft, Jose Candón-Mena and Ibán Díaz-Parra; Revision and editing, David Montero-Sánchez; Translation, David Montero-Sánchez. 


\section{Funding}

This research was funded by the R\&D Project "Cyberactivism, Digital Citizenship and New Urban Movements" (CiberMov). Programa Estatal de Fomento de la Investigación Científica y Técnica de Excelencia, Subprograma Estatal de Generación de Conocimiento del Ministerio de Economía y Competitividad (Ref: CSO201678386-P). FEDER funds.

\section{References}

Agudo,M.(2010).LondresnoesSevilla[Vídeo].Sevilla:IntermediaProducciones. http://videotecaalternativa.net/londres-no-es-sevilla-okupacion-y-desalojo-del-csoa-casas-viejas

Aguilar Fernández, S. y Fernández Gibaja, A. (2010). 'El movimiento por la vivienda digna en España o el porqué del fracaso de una protesta con amplia base social'. Revista Internacional de Sociología (RIS), 68 (3): 679-704. doi: 10.3989/ris.2008.12.01

Bertaux, D. (2005). Los relatos de vida. Perspectiva etnosociológica. Barcelona: Bellaterra.

Blanco, M. (2010). 'La autoetnografía como escritura terapéutica: Adiós al cigarro'. En C. Martínez (comp.), Por los caminos de la investigación cualitativa. Exploraciones narrativas y reflexiones en el ámbito de la salud. México: Universidad Autónoma Metropolitana-Xochimilco.

Callejo, J. (2001). El grupo de discusión. Introducción a una práctica de investigación. Barcelona: Ariel.

Candón-Mena, J. (2009). 'Smart Mobs y mensajes en cadena. Aproximación teórica a las convocatorias espontáneas de movilización social mediante redes telemáticas'. Redes.Com. Revista de Estudios para el Desarrollo Social de la Comunicación, 5: 255-281. http://hdl.handle.net/11441/13096

Candón-Mena, J. (2013). Toma las calles, toma las redes. El movimiento \#15M en Internet. Sevilla: Atrapasueños. http://hdl.handle.net/11441/26074

Capel, H. (1983). Capitalismo y morfología urbana. Barcelona: Universidad de Barcelona.

Carbonell, J. (1999). La lucha de barrios en Barcelona. Madrid: Elías Querejeta Ediciones.

Castells, M. (1983). The City and the Grassroots: A Cross-Cultural Theory of Urban Social Movements. Berkeley: University of California Press.

Chomsky, N. (2005). Chomsky on anarchism. Edimburgo y Okland: AK Press.

Clandinin, J. and Connelly, M. (1994). 'Personal Experience Methods'. In N. Denzin and Y. Lincoln (eds.), Handbook of Qualitative Research. California: SAGE.

Colau, A. and Alemany, A. (2012). Vidas Hipotecadas. Barcelona: Angle editorial.

De Miguel, J. M. (1996). Auto/biografías. Madrid: CIS. Colección cuadernos metodológicos.

Díaz, P. (2011). 'Los indignados se lanzan al rescate de los desahuciados'. Público. https:// www.publico.es/espana/indignados-lanzan-al-rescate-desahuciados.html

Díaz-Parra, I. (2008). 'Movimientos vecinales contra la gentrificación y transformaciones en la política local de Sevilla'. Actas del X Coloquio Internacional de Geocrítica, Universidad de Barcelona. http://www.ub.edu/geocrit/-xcol/8.htm 
Díaz-Parra, I. (2010). Sevilla, cuestión de clase. Una geografía social de la ciudad. Sevilla: Atrapasueños.

Díaz-Parra, I. (2012). 'Ocupación y fenómeno okupa: apreciaciones sobre la cuestión en el Estado español y sus perspectivas'. Revista de Servicios Sociales y Política Social, 97. http://www.serviciossocialesypoliticasocial.com/ocupacion-y-fenomeno-okupa-apreciaciones-sobre-la-cuestion-en-el-estado-espanol-y-sus-perspectivas

Díaz-Parra, I. (2013). 'La gentrificación en la cambiante estructura socioespacial de la ciudad'. Biblio 3W. Revista Bibliográfica de Geografía y Ciencias Sociales, 18(1030). http://www.ub.es/geocrit/b3w-1030.htm

Díaz-Parra, I. y Candón-Mena, J. (2014). 'Espacio geográfico y ciberespacio en el movimiento 15M'. Scripta Nova. Revista Electrónica de Geografía y Ciencias Sociales. 18(470). http://www.ub.es/geocrit/sn/sn-470.htm

Díaz-Parra, Ibán \& Candón-Mena, Jose (2015). 'Squatting, the 15-M movement, and struggles for housing in the context of the spanish social srisis'. Human Geography, 8(1); 40-53. http://hdl.handle.net/11441/28371

Dieste, J. y Pueyo, Á. (2003). 'Procesos de regeneración en el espacio urbano por las iniciativas de autogestión y okupación'. Scripta Nova. Revista electrónica de geografía $y$ ciencias sociales, 146(108). http://www.ub.es/geocrit/sn/sn-146(108).htm

Fernández, M.; Hernández, M. y Barragán, V. (2019). 'Rompiendo el consenso: comunidades virtuales y discurso contra-hegemónico en el movimiento contra la turistificación en Sevilla'. IC - Revista Científica de Información y Comunicación, 16:285-323. doi: https://dx.doi.org/10.12795/IC.2019.i19.09

Fuster, M. (2009). 'Action research: Mapping the nexus of research and political action'. Interface: a journal for and about social movements, 1(1):21-45. http://www.interfacejournal.net/2009/01/activist-research-methodologies_9685.html

García, A. (2011). De la 'V de vivienda'a los afectados por la hipoteca: la vivienda como objeto de batalla. Viento Sur, 116: 88-94. https://vientosur.info/spip.php?article6737

Greenwood, D. J. (2007). Pragmatic Action Research. International Journal of Action Research, 3(1+2), 131-148. https://nbn-resolving.org/urn:nbn:de:0168-ssoar-412899

Hale, C. R. (2006). Activist Research vs. Cultural Critique: Indigenous Land Rights and the Contradictions of Politically EngagedAnthropology. CulturalAnthropology, 21(1):96-120. https://www.jstor.org/stable/3651549

Haro Barba, C. y Sampedro Blanco, V. F. (2011). 'Activismo político en Red: del Movimiento por la Vivienda Digna al 15M'. Teknokultura, 8 (2): 157-175. https://revistas.ucm.es/index.php/TEKN/article/view/48025

Honorato, C. (2010). San Bernardo 52 [Video]. Sevilla: Atrapasueños.

Ibáñez, J. (1979). Más allá de la sociología. El grupo de discusión: técnica y crítica. Madrid: Siglo XXI.

Klandermans, B. (1988). 'The Formation and Mobilization of Consensus'. In B. Klandermans, H. Kriesi and S. Tarrow (eds.), International Social Movements Research, vol. 1. 173-196. Greenwich: JAI Press.

Koopmans, R. (2004). 'Protest in Time and Space: The Evolution of Waves of Contention'. In D. A. Snow; S. A. Soule and H. Kriesi (eds.) The Blackwell Companion to Social Movements. Malden, MA and Oxford, UK, Blackwell Publishing. 
Malo, M. (ed.) (2004). Nociones comunes. Experiencias y ensayos entre investigación y militancia. Madrid: Traficantes de Sueños.

Martínez López, M. (2002). Okupaciones de viviendas y de centros sociales. Barcelona: Virus editorial.

Martínez López, M. (2003). 'Viviendas y centros sociales en el movimiento de okupación'. Scripta Nova. Revista electrónica de geografía y ciencias sociales 146(109). http://www.ub.es/geocrit/sn/sn-146(109).htm

Martínez López, M. (2019). The autonomy of struggles and the self-management of squats: legacies of intertwined movements. Interface. A journal for and about social movements, 11 (1): 178-199.

Martínez López, M. (2020). 'European squatters movements and the right to the city'. In C. Flesher and R. A. Feenstra (eds.) Routledge Handbook of Contemporary European Social Movements Protest in Turbulent Times. Abingdon: Routledge.

Melucci, A. (1999). Acción Colectiva, Vida Cotidiana y Democracia. México: El Colegio de México.

Pujadas, J. J. (1992). El método biográfico. Uso de las historias de vida en las ciencias sociales. Madrid: CIS. Colección cuadernos metodológicos.

Sampedro-Blanco, V. F. (2005). 13-M Multitudes On-line. Madrid: Los Libros de la Catarata.

Tarrow, S. (1994). The Power in Movement: Social Movements and Contentious Politics. Cambridge: Cambridge University Press.

Vallés, M. S. (1997). Técnicas cualitativas de investigación social. Madrid: Síntesis.

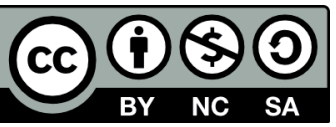

(C) 2022 by the authors. License to ANDULI, Editorial Universidad de Sevilla. This article is an open access article published under the terms and conditions of the license Creative Commons Attribution (CC BY) (https://creativecommons.org/ licenses/by-nc-sa/4.0/). 
